Jurnal Penelitian Perawat Profesional

Volume 3 Nomor 1, Februari 2021

e-ISSN 2715-6885; p-ISSN 2714-9757

http://jurnal.globalhealthsciencegroup.com/index.php/JPPP

\title{
TERAPI PADA DEMAM TIFOID TANPA KOMPLIKASI
}

\author{
Dicky Ardian Saputra \\ Fakultas Kedoktern, Universitas Lampung, Jl. Prof. DR. Ir. Sumatri Brojonegoro No.1, Gedong Meneng, \\ Kec. Rajabasa, Kota Bandar Lampung, Lampung, Indonesia 35145 \\ dickyardians23@gmail.com (+6281368654623)
}

\begin{abstract}
ABSTRAK
Demam tifoid merupakan suatu penyakit infeksi pada sistemik atau demam enterik yang diakibatkan oleh bakteri Salmonella enterica serovar typhi (S. typhi) . Pada perjalanan awal penyakit ini, biasanya tidak pasien tidak merasakan gejala dan keluhan, setelah ituakan timbul gejala yang khas seperti demam di sore hari dan serangkaian gejala infeksi umum yang akan dirasakan pasien pada saluran cerna. Tujuan dilakukannya literature review ini adalah untuk membahas tatalaksana yang tepat pada kasus demam tifoid tanpa komplikasi. Sumber referensi yang digunakan untuk menyusun tulisan ini meliputi 20 artikel yang didapat dengan melakukan literature searching di Sumber NCBI dan google schoolar yang dipublikasikan dalam rentang tahun 2000-2020. Literature sarching tersebut dilakukan dengan menggunakan kata kunci demam tifoid, tanpa komplikasi, terapi dan juga filter berupa rentang publikasi tahun 20002020. Hasil yang ditemukan dari literature searching ini adalah 5,420 artikel yang kemudian dipilih 20 artikel berdasarkan informasi yang dibutuhkan. Referensi yang telah dikumpulkan kemudian dianalisis dengan metode systematic literature review yang mencakup kegiatan mengumpulkan, mengevaluasi, dan mengembangkan penelitian dengan topik tertentu secara sistematis. Hasil literature review ini berupa Terapi pada demam tifoid tanpa komplikasi adalah berupa pemberian antibiotik tiamfenikol, kloramfenikol, atau ampisilin/amoksisilin, Sefalosporin generasi III, fluorokuinolon, azitromisin serta terapi suportif seperti pemeberian cairan dan juga bed rest.
\end{abstract}

Kata kunci: demam tifod; tanpa komplikasi; terapi

\section{THERAPY FOR THYPHOID FEVER WITHOUT COMPLICATION}

\section{ABSTRACT}

Typhoid fever is a systemic infectious disease or enteric fever caused by Salmonella enterica serovar typhi (S. typhi). At the onset of the disease, there are usually no symptoms or complaints and then symptoms or complaints arise such as afternoon fever and a series of symptoms of general and gastrointestinal infections. The purpose of conducting this literature review is to discuss the proper management of cases of typhoid fever without complications. The reference sources used to compile this paper include 20 articles obtained by conducting literature searching on NCBI and Google Schoolar Sources which were published in the 2000-2020 range. The sarching literature was carried out using the keyword typhoid fever, without complication and therapy and filters in the form of publication ranges from 2000-2020. The results found from this literature searching were 5,420 articles, then 20 articles were selected based on the required information. The references that have been collected are then analyzed using the systematic literature review method, which includes collecting, evaluating, and developing research with certain topics systematically. The results of this literature review are in the form of therapy for typhoid fever without complications in the form of administration of antibiotics thiamphenicol, chloramphenicol, or ampicillin / amoxicillin, third generation cephalosporins, fluoroquinolones, azithromycin and supportive therapy such as administration of fluids and bed rest. 
Keywords: Typhoid ; without complications; therapy

\section{PENDAHULUAN}

Demam tifoid adalah sutau infeksi sistemik yang disebabkan oleh bakteri $S$ typhi. Bakteri lain yang dapat menyebabkan demam tifoid adalah Salmonella enterica serovar paratyphi $\mathrm{A}, \mathrm{B}$, dan $\mathrm{C}$, penyakit ini disebut demam paratifoid. Demam tifoid dan paratifoid termasuk ke dalam demam enterik. Pada daerah endemik, sekitar 90\% dari demam enterik adalah demam tifoid (Pohan, 2011). Manusia merupakan satu-satunya reservoir dan penjamu utama dari Salmonella typhi . Bakteri Salmonella typhi mempunyai kemampuan bertahan hidup yang cukup baik. Bakteri ini bisa bertahan hidup dalam waktu berhari-hari di dalam air tanah, air kolam, atau air laut dan bakteri ini dapat bertahan selama berbulan-bulan lamanya dalam telur yang sudah terkontaminasi dan kerang tiram yang sudah dibekukan dalam waktu yang cukup lama (Bhan, Bahl, \& Bhatnagar, 2005).

Infeksi demam tifoid biasanya terjadi di musim kemarau dan pada permulaan musim hujan di daerah endemik. Jumlah bakteri tifoid yang dapat menjadi infeksius adalah jiika 103-106 organisme masuk atau tertelan secara oral oleh manusia. Demam tifoid dapat menular melalui makanan dan air yang terkontaminasi oleh feses. Insidens demam tifoid di Indonesia banyak dijumpai pada populasi dengan usia antara 3-19 tahun. Demam tifoid yang terjadi di Indonesia mempunyai kaitan erat dengan rumah tangga, seperti terdapatnya keluarga dengan riwayat pernah terkena demam tifoid sebelumnya, tidak tersedianya sabun untuk mencuci tangan di rumah, menggunakan peralatan makan yang sama dalam satu keluarga (Nurlaila, Trisnawati, \& Selviana, 2015).

Penularan demam tifoid dapat terjadi dari menelan makanan dan minuman yang telah terkontaminasi oleh bakteri tifoid, dan dapat juga karena adanya kontak langsung jari tangan yang sudah terkontaminasi oleh tinja yang mengandung bakteri tifoid, secret saluran nafas atau dengan pus dari penderita yang sudah terinfeksi bakteri tersebut (Dian, 2007). Proses terkontaminasinya makanan atau minuman dipengaruhi juga oleh faktor lain berupa pengolahan bahan makanan yang tidak bersih dan perilaku dari kebersihan perorangan yang kurang baik sehingga banyaknya bakteri yang ditemukan pada tangan (Rahayu, 2000).

Pathogenesis dari demam tifoid teridri dari 3 proses yaiu (1) Invasi oleh bakteri Salmonella typhi ke sel epitel dinding usus manusia (2) proses bertahan hidup dari bekteri tersebut dalam makrofag dan (3) proses replikasi dari bakteri tersebut dalam makrofag. Bakteri $S$ typhi masuk ketubuh melalui mulut diperantarai oleh makanan dan minuman yang dikonsumsi. Setelah bakteri masuk ke lambung akan bakteri tersebut akan berusaha bertahan hidup dari asam lambung dengan zat kimia yang di hasilkannya (Widoyono, 2011).

Gejala klinis utama dari demam tifoid yang sering dijumpai adalah demam. Gejala demam pada demam tifoid akan meningkat secara perlahan dari menjelang sore dan mencapai puncak pada malam hari dan akan mengalami penurunan pada siang hari. Demam akan terus meningkat hingga $39-40^{\circ} \mathrm{C}$ dan demam akan menetap pada minggu kedua infeksi. Masa inkubasi dari 
bakteri tifoid yaitu sekitar 7 sampai 14 hari. Gejala infeksi pada demam tifoid tidak spesifik dan seperti infeksi lainnya, gejalanya berupa sakit kepala, nausea, nyeri perut, myalgia, arthralgia, demam, anoreksia serta konstipasi (Levani \& Prastya, 2020).

Pada pemeriksaan fisik pada pasien demam tifoid biasanya ditemukan bradikardi relatif, lidah kotor, demam tinggi, adanya hepatomegali, nyeri tekan pada abdomen, adanya splenomegali dan rose spot. Rose spot adalah kumpulan dari lesi berukuran makulopapular dengan eritematus diameter 2-4 $\mathrm{mm}$ yang dapat ditemukan pada dada dan perut pasien. Tanda rose spot pada pasien demam tifoid ini ditemukan 5 sampai $30 \%$ pada kasus dan tidak akan terlihat pada pasien dengan kulit yang gelap. Gejala klinis demam tifoid yang diakibatkan oleh bakteri Salmonella paratyphi lebih ringan dari gejala demam tifoid yang diakibatkan oleh bakteri Salmonella typhi (Chanh et al., 2004).

Diagnosis dari demam tifoid di tegakkan dengan pemeriksaan darah tepi seperti jumlah trombosit, leukosit dan eritrosit, biasanya tidak spesifik untuk menegakkan diagnosis dari demam tifoid. Leukopenia pada demam tifoid sering ditemukan pada kasus demam tifoid, tetapi jumlah leukosit jarang kurang dari 2.500/mm3. Kondisi leukopenia dapat menetap 1 sampai 2 minggu setelah infeksi. Pada kondisi tertentu, jumlah leukosit dapat ditemukan meningkat (20.00025.000/mm3). Penegakkan diagnosis demam tifoid lainnya dapat di lakukan dengan uji typhidot, yaitu untuk mendeteksi antibodi IgM dan IgG yang terdapat pada protein membran bakteri Salmonella typhi. Uji ini dapat dilakukan dengan hasil positif 2-3 hari pasca terinfeksi dengan sensitivitas $98 \%$, spesifisitas sebesar 76,6\%. Uji ini hampir sama dengan pemeriksaan uji tubex (Crump, Sjölund-Karlsson, Gordon, \& Parry, 2015).

Pemeriksaan Widal pada demam tifoid berperan dalam mendeteksi antibodi yang dihasilkan karena adanya antigen Salmonella typhi, namun pemeriksaan masih kontroversial. Antibodi antigen $\mathrm{O}$ pada demam tifoif dijumpai di hari 6-8 dan antibodi antigen $\mathrm{H}$ akan dijumpai di hari 10-12 setelah terjadinya infeksi. Pada orang yang sudah mengalami infeksi dan sudah sembuh, antibodi $\mathrm{O}$ masih dijumpai setelah 4-6 bulan terjadi infeksi dan antibodi $\mathrm{H}$ akan masih di jumpai setelah 10-12 bulan. Oleh karena itu pemeriksaan widal tidak dapat digunakan sebagai penentu menentukan kesembuhan penyakit demam tifoid. Diagnosis demam tifoid dapat ditegakkan atas dasar kenaikan titer sebanyak 4 kali pada dua pengambilan darah dengan selang hanya beberapa hari dan bila klinis dapat mengacu pada hasil pemeriksaan titer widal dari pasien di atas rata-rata titer orang sehat pada wilayah pasien tinggal (Mehta, 2008).

Demam tifoid merupakan suatu penyakit yang sering di jumpai di indonesia, namun penyakit ini tidak dapat dianggap remeh karena jika tidak ditangani dengan tepat maka akan menimnulkan komplikasi yang cukup serius. Penegakan diagnosis yang awal dan sedini mungkin akan berguna untuk pemberian terapi yang tepat pada pasien dan dapat mengurangi risiko terjadinya komplikasi.(Levani \& Prastya, 2020).

Tujuan penulisan literature review ini adalah untuk mengetahui bagaimana tatalaksana yang tepat pada kasus demam tifoid tanpa kompliasi. Literature review ini perlu dilakukan 
agar memudahkan pembaca untuk mengetahui informasi terkait penanganan demam tifoid.

\section{METODE}

Penulisan artikel ini menggunakan metode literature review. Tulisan ini terbentuk atas informasi yang didapat dari 20 artikel dari jurnal internasional dan 1 buku yang dipublikasikan dalam rentang tahun 2000-2020. Referensi yang digunakan didapat dengan melakukan literature searching dari database NCBI dengan kata kunci typhoid fever; therapy dan filter berupa rentang publikasi tahun 2000-2020. Hasil yang ditemukan dari literature searching ini adalah 5,420 artikel yang kemudian dipilih 20 artikel berdasarkan informasi yang dibutuhkan. Artikel terpilih kemudian dianalisis dengan metode systemic literature review yang mencakup aktivitas pengumpulan, evaluasi, dan pengembangan penelitian dengan fokus tertentu.

\section{HASIL}

Tatalaksana atau terapi dari pada demam tifoid bertujuan untuk mencapai suhu normal, menghilangkan gejala lain, mencegah terjadinya komplikasi, dan juga menghindari terjadinya kematian pada pasien. Hal lain yang juga sangat penting dalam tatalaksana demam tifoid tanpa komplikasi adalah mengeradikasi total bakeri untuk mencegah terjadinya kekambuhan dan juga keadaan carrier pada saat setelah terkena penyakit ini (Bhan, Bahl, \& Bhatnagar, 2005). pada daerah endemik, sebanyak 60\%-90\% jumlah kasus demam tifoid dapat di tangani dengan pemberian terapi antibiotik dan juga bed rest. Antibiotik yang sangat awal menjadi terapi untuk demam tifoid adalah kloramfenikol. Namun pada tahun 1990an peneliti mulai menemukan adanya resistensi dari Salmonella thypi terhadap antibiotik kloramfenikol. Antibiotik yang menjadi lini utama dari tereapi demam tifoid pada saat ini adalah antibiotik golongan fluoroquinolon (Mirza, Beeching, \& Hart, 1996).

Ada beberapa antibiotik pada saat ini yang digunakan sebagai terapi lini pertama pada demam tifoid diantaranya adalah, kloramfenikol, tiamfenikol atau amoksisilin/ ampisilin. Pemberian antibiotik kloramfenikol pada demam tifoid biasanya dapat menimbulkan beberapa efek samping, diantaranya adalah penekanan sumsum tulang dan dan juga yang parah dapat terjadinya anemia aplastic pada pasien. Selanjutnya adalah antibiotik golongan Sefalosporin generasi III (sefotaksim, seftriakson sefiksim), fluorokuinolon (ofloksasin, siprofloksasin, perfloksasin) dan pada saat ini azitromisin juga digunakan sebagai terapi pada demam tifoid (Rampengan, 2016).

Pemilihan antibiotik untuk terapi demam tifoid akan bergantung pada pola sensitivitas isolat dari bakteri Salmonella typhi dari lingkungan tempat tinggal pasien tersebut. Adanya resistensi dari galur Salmonella typhi terhadap beberapa antibiotik dari kelompok MDR ini akan dapat mengurangi pilihan antibiotik yang akan diberikan pada pasien demam tifoid. Resistensi antibiotik dari salmonella thypi terbagi menjadi 2 kategori yaitu resisten terhadap antibiotik dari kelompok ampicillin, chloramphenicol, dan juga dari kelompok trimethoprimsulfamethoxazole yaitu kelompok MDR dan yang kedua adalah resisten terhadap antibiotik fluoroquinolone. Nalidixic acid resistant Salmonella typhi atau yang biasa disebut dengan NARST adalah suatu 
petanda dari berkurangnya sensitivitas Salmonella thypi terhadap antibiotik fluoroquinolone. Antibiotik Fluoroquinolone bekerja dengan cara membunuh $S$. Typhi intraseluler di dalam monosit/makrofag (Nelwan, 2012).

\section{PEMBAHASAN}

Tatalaksana demam tifoid tanpa komplikasi adalah berupa pemeberian antibiotik golongan fluoroquinolone, diantaranya adalah ciprofl oxacin, ofl oxacin, dan pefloxacin. Pemebrian antibiotik golongan fluoroquinolone pada demam tifoid cukup efektif, karena isolat dari bakteri Salmonella tyhpi tidak resisten terhadap golongan fluoroquinolone. Angka kesembuhan dari pemberian antibiotik golongan fluoroquinolone mencapai $98 \%$, demam akan turun dalam 4 hari, dan angka fecal carrier dan kekambuhan kurang dari 2\% (Bhan, Bahl, Bhatnagar, 2005). Cara kerja dari antibiotik golongan Fluorokuinolon ini adalah dengan cara menghambat enzim topoisomerase II (DNA gyrase) dan topoisomerase IV yang akan diperlukan oleh bakteri Salmonella thypi untuk melakukan replikasi DNA. Golongan antibiotik ini dapat membentuk suatu ikatan yang kompleks dengan enzim topoisomerase II (DNA gyrase) dan topoisomerase IV dan juga dengan DNA bakteri. Sehingga antibiotik ini akan mengakibatkan hambatan yang menghasilkan efek sitotoksik ke dalam sel target (Raini, 2016).

Beberapa fluorokuinolon aktif melawan dormant dan bakteri bereplikasi. Cara kerja dari antibiotik golongan fluorokuinolon termasuk siprofloksasin berbeda dengan golongan antibiotik lainnya seperti makrolida, beta lactam, aminoglikosida atau tetrasiklin. karena itu organisme yang sudah menjadi resisten terhadap antibiotik golongan ini dapat masih sensitif dengan antibiotik siprofloksasin (Sharma \& Jain, 2009).

Antibiotik golongan Fluoroquinolone mempunyai kemampuan penetrasi yang sangat baik ke dalam jaringan, antibioik ini dapat membunuh bakteri S. Typhi secara intraseluler di dalam sel monosit/makrofag, antibiottik ini dapat mencapai kadar yang cukup tinggi di dalam kandung empedu jika dibandingkan dengan antibiotik lainnya (Nelwan., 2012). Salah satu antibiotik dari golongan fluoroquinolone yang saat ini telah diketahui memiliki efektivitas yang cukup baik dalam mengatasi demam tifoid adalah levofloxacin. Pada penelitian sebelumnya dilakukan perbandingan antara levofloxacin dengan obat standar ciprofloxacin untuk terapi demam tifoid tanpa komplikasi, denganb dosis Levofloxacin diberikan sebanyak $500 \mathrm{mg}$, untuk 1 kali sehari dan antibiotik ciprofloxacin diberikan dengan dosis $500 \mathrm{mg}$, untuk 2 kali sehari, kedua antibiotik ini diberikan selama 7 hari. Kesimpulan yang didapat dari studi ini berupa levofloxacin lebih bermanfaat dan efektif jika dibandingkan dengan ciprofloxacin dalam hasil mikrobiologi, waktu penurunan demam, dan juga antibiotik ini memiliki efek samping yang jauh lebih sedikit dibandingkan jumlah efek samping yang ditimbulkan oleh ciprofloxacin (Nelwan et al., 2013).

Pemberian antibiotik kloramfenikol dan tiamfenikol sebagai tereapi demam tifoid masih cukup sensitive dan efektif. Tiamfenikol merupakan antibiotik turunan dari antibiotik kloramfenikol, antibiotik ini juga aktif terhadap spesies Salmonella dan diberikan secara oral. Antibiotik ini dapat diberikan dengan dosis yang lebih kecil, intervalnya lebih 
lama, dengan angka kekambuhan, dan angka terjadinya carrier yang lebih sedikit. Efek samping yang ditimbulkan oleh antibiotik ini adalah dapat terjadinya depresi dari sumsum tulang, tetapi untuk efek samping anemia aplastik hampir tidak pernah terjadi. Antibiotik tiamfenikol dapat menurunkan demam dan menormalkan suhu dalam waktu 3-5 hari pada remaja dan dewasa dan lama pengobatan dari antibiotik ini adalah sekitar 7-14 hari. Tiamfenikol dapat dijadikan sebagai obat pilihan pertama menggantikan kloramfenikol dalam pengobatan demam tifoid. Pemberian tiamfenikol pada anak masih harus diteliti lebih lanjut karena angka kekambuhan dan terjadinya carrier masih tinggi (Rismarini, Anwar, \& Merdjani, 2016).

Salah satu terapi antbiotik lain yang dapat diberikan pada pasien demam tifoid adalah azitromisin. Azitromisin merupakan antibiotic dari golongan makrolid pertama yang termasuk ke dalam kelas azalide. Pemberian azitromisin pada terapi demam tifoid tanpa komplikasi pada anak dan dewasa terbukti efektif, untuk lama penurunan suhu dari demam tercatat sama dengan lama waktu penurunan suhu yang diperlukan oleh kloramfenikol. Azitromisin dapat diberikan dengan dosis $10 \mathrm{mg} / \mathrm{kgBB}$ selama 7 hari (WHO, 2003). Pada penelitian invitro sebelumnya menunjukkan hasil berupa antibiotik azitromisin lebih poten terhadap bakteri Salmonella spp jika dibandingkan dengan obat lini pertama dan makrolid yang lainnya. Penelitian lainnya menunjukkan bahwa antibiotik azitromisin efektif secara bakteriologis dan klinis dalam mengobati demam tifoid bahkan yang disebabkan oleh bakteri dengan strain MDR. Perbedaan dari azitromisin dan kloramfenikol adalah dalam hal, farmakokinetik, cara pemberian, efek samping dan prinsip terapi, kloramfenikol diberikan empat kali sehari sedangkan untuk azitromisin lebih sedikit yaitu diberikan sekali sehari. Kedua antibiotik ini dapat berpenetrasi ke dalam sel secara efektif, dan hal tersebut menerangkan aktivitas terapeutik obat terhadap patogen yang berada di intraselular seperti S. typhi. Antibiotik lain yang juga digunakan sebagai terapi demam tifoid adalah sefiksim. Sefiksim adalah antibiotik dari golongan sefalosporin generasi ketiga dengan pemberian oral, sefiksim memiliki aktifitas antimikroba terhadap bakteri Gram positif dan juga negatif termasuk bakteri Enterobacteriaceae. Sefiksim merupakan antibiotik yang mempunyai toleransi dan efikasi yang baik untuk pengobatan demam tifoid pada anak (Rampengan, 2016).

Terapi pada demam tifoid tidak hanya berupa pemberian antibiotik, namun juga dapat berupa terapi suportif dan istirahat (bed rest). Terapi suportif pada demam tifoid dapat diberupa pemeberian cairan dengan tujuan untuk mengkoreksi adanya ketidakseimbangan elektrolit dan cairan. Sedangkan pemberian antipiretik pada demam tifoid bertujuan untuk menurunkan suhu dari demam hingga suhu normal, antipiretik yang biasa digunakan pada demam tifoid adalah paracetamol 500 mg yang dapat diberikan 3 kali dalam sehari. Pemberian nutrisi yang adekuat juga dapat menjadi terapi yang tepat pada demam tifoid, pemberian nutri melalui TPN, pemberian makanan dapat berupa makanan yang lembut dan mudah untuk dicerna pasien (Brutha, 2006). 
Tabel 1.

Antibiotik yang diberikan pada demam tifoid tanpa komplikasi menurut WHO 2003

\begin{tabular}{|c|c|c|c|c|c|c|}
\hline & \multicolumn{3}{|c|}{ Optimal therapy } & \multicolumn{3}{|c|}{ Alternative effective drugs } \\
\hline $\begin{array}{l}\text { Susceptibi } \\
\text { lity }\end{array}$ & antibiotic & $\begin{array}{l}\text { Daily } \\
\text { dose } \\
\mathrm{mg} / \mathrm{kg}\end{array}$ & days & antibiotic & $\begin{array}{l}\text { Daily } \\
\text { dose } \\
\mathrm{mg} / \mathrm{kg}\end{array}$ & days \\
\hline $\begin{array}{c}\text { Fully } \\
\text { sensitive }\end{array}$ & $\begin{array}{l}\text { Fluoroquinolone } \\
\text { e.g.ofloxacin or } \\
\text { ciprofloxacin }\end{array}$ & 15 & $5-7$ & $\begin{array}{l}\text { Chloramphenico } \\
1 \text { amoxicillin } \\
\text { TMP-SMX }\end{array}$ & $\begin{array}{c}50-75 \\
75-100 \\
8-40\end{array}$ & $\begin{array}{c}14-21 \\
14 \\
14\end{array}$ \\
\hline $\begin{array}{l}\text { Multidrug } \\
\text { resistance }\end{array}$ & $\begin{array}{c}\text { Fluoroquinolone } \\
\text { or cefixime }\end{array}$ & $\begin{array}{c}15 \\
15-20\end{array}$ & $\begin{array}{c}5-7 \\
7-14\end{array}$ & $\begin{array}{l}\text { Azithromycin } \\
\text { cefixime }\end{array}$ & $\begin{array}{c}8-10 \\
15-20\end{array}$ & $\begin{array}{c}7 \\
7-14\end{array}$ \\
\hline $\begin{array}{l}\text { Quinolone } \\
\text { resistance }\end{array}$ & $\begin{array}{l}\text { Azithromycin or } \\
\text { ceftriaxone }\end{array}$ & $\begin{array}{c}8-10 \\
75\end{array}$ & $\begin{array}{c}7 \\
10-14\end{array}$ & cefixime & 20 & $7-14$ \\
\hline
\end{tabular}

\section{SIMPULAN}

Terapi pada demam tifoid tanpa komplikasi adalah berupa pemberian antibiotik tiamfenikol, kloramfenikol, Sefalosporin generasi III (sefotaksim, seftriakson, sefiksim), fluorokuinolon (ofloksasin, siprofloksasin, perfloksasin) atau ampisilin/ amoksisilin, dan azitromisin pada saat ini juga sering digunakan sebagai terapi pada demam tifoid. Pemberian antipiretik juga dapat digunakan sebagai terapi pada demam tifoid untuk menurunkan suhu dan menghilangkan gejala demam. Terapi lain yang juga dapat diberikan pada demam tifoid tanpa komplikasi adalah terapi suportif seperti pemeberian cairan dan juga bed rest.

\section{DAFTAR PUSTAKA}

Bhan, M. K., Bahl, R., Bhatnagar, S. (2005) Typhoid fever and paratyphoid fever. Lancet, 366: 749-762.

https://doi.org/10.1016/S0140673 $\underline{6(05) 67181-4}$

Chanh, N. Q., Everest, P., Khoa, T. T., House, D., Murch, S., Parry, C., ... Wain, J. (2004). A clinical, microbiological, and pathological study of intestinal perforation associated with typhoid fever. Clinical Infectious Diseases, 39(1), 61-67. https://doi.org/10.1086/421555

Crump, J. A., Sjölund-Karlsson, M., Gordon, M. A., \& Parry, C. M. (2015). Epidemiology, clinical presentation, laboratory diagnosis, antimicrobial resistance, and antimicrobial management of invasive Salmonella infections. Clinical Microbiology Reviews, 28(4), 901-937. https://doi.org/10.1128/CMR.000 02-15

Dian. 2007. Studi Biologi Molekuler Resistensi Salmonella Typhi Terhadap Kloramfenikol. ADLN Digital Colectio

Effa, E. E., Bukirwa, H. (2008). Azitromisin for treating uncomplicated typhoid and paratyphoid fever (enteric fever). Cochrane Library, 8(4), CD006083.

https://doi.org/10.1002/14651858. CD006083.pub3

Levani, Y., \& Prastya, A. D. (2020). Demam Tifoid: Manifestasi Klinis, Pilihan Terapi Dan 
Pandangan Dalam Islam. Al-Iqra Medical Journal : Jurnal Berkala Ilmiah Kedokteran, 3(1), 10-16. https://doi.org/10.26618/aimj.v3i1 .4038

Linson, M., Bresnan, M., Eraklis, A., \& Shapiro, F. (1981). Acute gastric volvulus following harrington rod instrumentation in a patient with werdnig-hoffman disease. Spine, 6(5), 522-523. https://doi.org/10.1097/00007632198109000-00015

Mehta, K. K. (2008). Changing trends in enteric fever. Medicine, 18, 201-204.

Mirza, S. H., Beeching, N. J., \& Hart, C. A. (1996). Multi-drug resistant typhoid: A global problem. Journal of Medical Microbiology, 44(5), 317-319. https://doi.org/10.1099/0022261544-5-317

Nelwan, R., Chen Lie, K., Hadisaputro, S., Suwandoyo, E., \&nbsp, S., \&nbsp, N., ... Paramita, D. (2013). A Single Blind Comparative Randomized NonInferior Multicenter Study for Efficacy and Safety of Levofloxacin versus Ciprofloxacin in the Treatment of Uncomplicated Typhoid Fever. Advances in Microbiology, 03(01), 122-127. https://doi.org/10.4236/aim.2013. 31019

Nelwan, R., Chen Lie, K., Nafrialdi, Paramita D. (2006). Open study on effi cacy and safety of levofl oxacin in treatment of uncomplicated typhoid fever. Southeast Asian J Trop Med Public Health, 37(1), 126-130.
Nurlaila, S., Trisnawati, E., \& Selviana. (2015). Faktor-faktor yang Berhubungan Dengan Demam Tifoid pada Pasien yang Dirawat di RSU.DR.Soedarso Pontianak Kalimantan Barat. Jurnal Mahasiswa Dan Peneliti Kesehatan, 2(1), 54-66. http://dx.doi.org/10.29406/jjum.v $2 \mathrm{i} 1.154$

Pohan, H. T. (2011). Management of resistant Salmonella infection. Paper presented at: 12th Jakarta Antimicrobial Update; April 1617; Jakarta, Indonesia

Rahayu. (2000). Faktor Risiko Kejadian Demam Tifoid Penderita yang Dirawat Di RSUD Dr. Soetomo. Tesis. Surabaya: Universitas Airlangga.

Raini, M. (2016). Fluoroquinolones Antibiotics: Benefit and Side Effects. Pusat Penelitian Dan Pengembangan Biomedis Dan Teknologi Dasar Kesehatan, Badan Litbangkes, Kemenkes RI, 26(3), 163-174.

Rampengan, N. H. (2016). Antibiotik Terapi Demam Tifoid Tanpa Komplikasi pada Anak. Sari Pediatri, 14(5), 271. https://doi.org/10.14238/sp14.5.20 13.271-6

Rismarini, R., Anwar, Z., \& Merdjani, A. (2016). Perbandingan Efektifitas Klinis antara Kloramfenikol dan Tiamfenikol dalam Pengobatan Demam Tifoid pada Anak. Sari Pediatri, 3(2), 83.https://doi.org/10.14238/sp3.2. 2001.83-7

Sharma, P. C., Jain, A., \& Jain, S. (2009). Fluoroquinolone antibacterials: A review on 
chemistry, microbiology and therapeutic prospects. Acta Poloniae Pharmaceutica - Drug Research, 66(6), 587-604.

WHO, 2003, Diagnosis of Typhoid Fever. Dalam: Background Document: The Diagnosis Treatment and Prevention of Typhoid Fever. Word Health Organization.

Widoyono. (2011). Penyakit Tropis. Erlangga. Jakarta. 
Jurnal Penelitian Perawat Profesional, Volume 3 No 1 Hal 213 - 222, Februari 2021 Global Health Science Group 